\title{
Selenium in the Treatment of Head and Neck Lymphedema
}

\author{
F. Bruns ${ }^{a, b, f}$ J. Büntzele,f R. Mücke ${ }^{d, f} \quad$ K. Schönekaes ${ }^{f}$ K. Kisters ${ }^{e, f}$ \\ O. Micke ${ }^{b, f}$
}

a Department of Radiotherapy, Medical School Hannover, Hannover, bDepartment of Radiotherapy, Münster University Hospital, Münster, ' Department of Otolaryngology, Community Hospital Nordhausen, Nordhausen, ${ }^{\mathrm{d} D e p a r t m e n t}$ of Radiotherapy, Community Hospital Weiden, Weiden, and eDepartment of Internal Medicine, St. Anna Hospital Herne, Herne, Germany; ${ }^{f}$ German Working Group Trace Elements and Electrolytes in Radiation Oncology (AKTE)

\section{Key Words}

Selenium · Sodium selenite · Glutathione peroxidase • Radiotherapy · Head and neck cancer - Lymphedema • Endolaryngeal edema

\begin{abstract}
Objective: To investigate the impact of selenium in the treatment of lymphedema of the head and neck region after radiotherapy alone or in combination with surgery. Subjects and Materials: Between June 1996 and June 2001 a total of 36 cancer patients (29 male, 7 female; median age 61 years) were treated with selenium for persistent, extensive or progressive lymphedema of the head and neck region. Twenty had interstitial endolaryngeal edema associated with stridor and dyspnea. All patients received $350 \mu \mathrm{g} / \mathrm{m}^{2}$ body surface sodium selenite medication p.o. daily (total dose $50 \mu \mathrm{g}$ per day) for a period of 4-6 weeks after radiotherapy. The optimal effect of the selenium treatment was assessed after 4 weeks of therapy using the Miller score system. A visual analogue scale on a scale of 0-10 was used to assess the patient's quality of life prior to and after selenium. Results: $75 \%$ of the patients had an improvement of the
\end{abstract}

Presented at the 3rd International Symposium on Trace Elements in Human: New Perspectives, Athens, Greece, October 4-6, 2001.
Miller score of one stage or more. The self-assessment of quality of life using the visual analogue scale improved significantly after selenium treatment with a reduction of 4.4 points $(p<0.05)$. Of the 20 patients with endolaryngeal edema tracheostomy was not necessary in 13 patients $(65 \%)$, but 5 and 2 received a temporary or permanent tracheostomy, respectively. No episode of erysipelas was observed in all study patients. Conclusion: Our results suggest a short positive effect of sodium selenite on secondary head and neck lymphedema caused by radiotherapy alone or in combination with surgery.

Copyright $\odot 2004$ S. Karger AG, Base

\section{Introduction}

Lymphedema can be defined as a set of pathologic conditions in which there is an excessive interstitial tissue fluid accumulation. In contrast with venous edema, in which enhanced capillary pressure can indirectly stimulate lymph production, lymphedema is caused by a reduction in lymphatic transport leading to lymphatic stasis resulting from either congenital or acquired anomalies caused by the obstruction or interruption of the lymphatic flow at the site of the lymph nodes [1-4]. In cancer patients, secondary lymphedema can also develop as a result of surgically induced damage to lymphatic vessels

\begin{tabular}{|c|c|}
\hline KARGER & $\begin{array}{l}\text { (c) 2004 S. Karger AG, Basel } \\
1011-7571 / 04 / 0134-0185 \$ 21.00 / 0\end{array}$ \\
\hline $\begin{array}{l}\text { Fax + 41613061234 } \\
\text { E-Mail karger@karger.ch } \\
\text { www.karger.com }\end{array}$ & $\begin{array}{l}\text { Accessible online at: } \\
\text { www. karger.com/mpp }\end{array}$ \\
\hline
\end{tabular}

Dr. Oliver Micke

Klinik und Poliklinik für Strahlentherapie-Radioonkologie

Universitätsklinikum Münster, Albert-Schweitzer-Strasse 33

DE-48129 Münster (Germany)

Tel. +49 251 8347839, Fax +49 251 8347355, E-Mail omicke@trace-elements.de 
Table 1. Treatment characteristics

\begin{tabular}{lll}
\hline Diagnosis & Surgical procedure & Radiotherapy \\
\hline Head and neck malignancies $(n=36)$ & Unresectable tumors $(n=22)$ & Unresectable tumors $(n=22)$ \\
Hypopharyngeal carcinoma $(\mathrm{n}=19)$ & Biopsy only & 70.2 Gy to the primary tumor region, \\
Oropharyngeal carcinoma $(\mathrm{n}=9)$ & Resected tumors $(n=14)$ & 54 Gy to the regional lymphatic drainage \\
Laryngeal carcinoma $(\mathrm{n}=3)$ & Radical tumor resection, & Resected tumors $(n=14)$ \\
Oral cavity carcinoma $(\mathrm{n}=5)$ & bilateral neck dissection $(\mathrm{n}=14)$ & $60-66$ Gy to the primary tumor region, \\
& & 54 Gy to the regional lymphatic drainage
\end{tabular}

and obstructions in the lymphatic flow (e.g. lymph node dissection) or by radiotherapy [1,3-5].

A large variety of different treatments for lymphedema have been proposed $[1,5-8]$. The standard treatment for the edema of the extremities is the use of a compression garment, exercises, and skin care, mostly in combination with physical decongestive therapy $[1,5,6,9]$, manual drainage, and drug. The most commonly used drugs in lymphedema treatment are benzopyrones and proteolytic enzymes [10]. Although benzopyrones have been shown to improve chronic lymphedema [11-13], it has an intolerable rate of $6 \%$ hepatotoxicity; hence its long-term use is not recommended [14, 15].

Since lymphedema has been recognized as one of the major problems of patients with breast cancer and as such limiting their quality of life, manual lymphatic drainage has become the therapy of choice for this condition $[1,3$, 6, 16-18]. Despite the high success rates, however, there remains a group of patients with persistent or progressive lymphedema. It has been reported that these patients may benefit from an additional adjuvant therapy such as selenium $[8,9,20,21]$.

Other drugs, such as corticosteroids and diuretics, may be useful in edema of mixed origin and in palliative circumstances, but cannot be recommended for persistent lymphedemas. Corticosteroids produce a fast, but only short-lasting reduction of swelling and promote the susceptibility of infections in chronic lymphedema. Diuretics generate a fast depletion of fluid, but result in a higher protein concentration in edematous tissue, and therefore promote fibrosclerotic processes $[9,15,21]$. Hence the need for an additional adjuvant therapy such as selenium, a free-radical scavenger with well-described antiedematous effect $[5,9,15,17,22,23]$.

Therefore, the aim of this explorative study was to evaluate the effect of selenium in the treatment of lymphedema of the head and neck region.

\section{Materials and Methods}

This study was approved by the institution's ethics committee and was carried out in accordance with the Helsinki Declaration.

\section{Study Patients}

Between June 1996 and June 2001, a total of 36 head and neck cancer patients ( 29 male, 7 female) were treated for persistent, extensive or progressive lymphedema of the head and neck region. Median age of patients was 61 years (range: $47-79$ years). All patients complained that lymphedema compromised their quality of life. Twenty patients had interstitial endolaryngeal edema, associated with stridor and dyspnea, and initially graded $3(n=12)$ or $4(n=8)$, which would generally be treated with tracheostomy. The median interval between the end of radiotherapy and the beginning of selenium treatment was 4 months (range: 2-12 months). The maximal treatment effect was assessed 4 weeks after the end of selenium treatment. Cancer treatment characteristics are summarized in table 1 .

\section{Selenium Medication}

All patients received $350 \mu \mathrm{g} / \mathrm{m}^{2}$ body surface sodium selenite (Selenase $^{\circledR}$, Biosyn Arzneimittel GmbH, Fellbach, Germany) p.o. daily, generally resulting in a total dose of $500 \mu \mathrm{g}$ per day. All patients received this medication over a period of 4-6 weeks (median: 5 weeks). Thus, the median total costs of the selenium therapy were $\$ 1,663$ (daily costs: $\$ 49$ ). No patient received additional antiedematous medications such as steroids or benzopyrones.

\section{Treatment Evaluation}

For head and neck edema, no grading system has yet been established. Therefore, a modified clinical grading system was investigated to obtain an objective structure of our data base. Interstitial endolaryngeal edema was clinically graded using a score adopted from the LENT-SOMA system [24, 25] without additional assessment of phonatory characteristics. The extent of other lymphedemas of the head and neck area was graded using the modified scoring systems of Földi [7] and Földi et al. [26] and of Miller et al. [27].

The LENT-SOMA system graduates organ-specific late toxicities (late effects on normal tissues, LENT) after radiotherapy integrating well-defined subjective ('S') and objective ('O') parameters as well as management ('M') and analysis ('A') methods [25]. The scoring systems according to Földi et al. [26] and Miller et al. [27] are classification systems based on descriptive characteristics of lymphedema at various levels of severity including special complications [7, 21, 26, 27]. Both classification systems are well established particularly for 
Table 2. Classification characteristics

\begin{tabular}{|c|c|c|c|}
\hline \multicolumn{4}{|l|}{ Scoring system } \\
\hline $\begin{array}{l}\text { Modified Földi score for head } \\
\text { and neck edema }[7,26]\end{array}$ & $\begin{array}{l}\text { Development } \\
\text { latency } \\
\text { reversibility } \\
\text { spontaneous irreversibility } \\
\text { permanent irreversibility }\end{array}$ & $\begin{array}{l}\text { Clinical symptoms } \\
\text { no signs of swelling, no clinical s } \\
\text { clinical signs of swelling, edema } \\
\text { skin thickening, no pitting on pre } \\
\text { clinical signs of elephantiasis, ve } \\
\text { functional loss }\end{array}$ & $\begin{array}{l}\text { ptoms, only histological changes } \\
\text { s, some decreased function } \\
\text { ure, marked functional loss, loss of joint flexibility } \\
\text { ccous vesicles, keratotic papules, complete }\end{array}$ \\
\hline $\begin{array}{l}\text { Modified Miller score for head } \\
\text { and neck edema [27] }\end{array}$ & $\begin{array}{l}\text { Inspection } \\
\text { normal } \\
\text { normal appearance } \\
\text { yellowish discoloration } \\
\text { lichenification, early keratotic } \\
\text { changes, small vesicles } \\
\text { or keratotic papules } \\
\text { additional increased yellowish } \\
\text { discoloration and pigmentation, } \\
\text { weeping vesicles }\end{array}$ & $\begin{array}{l}\text { Palpation } \\
\text { normal } \\
\text { edema pits on pressure } \\
\text { additional early skin thickening } \\
\text { skin thickening, little pitting } \\
\text { on pressure } \\
\text { skin thickening, no pitting } \\
\text { on pressure }\end{array}$ & $\begin{array}{l}\text { Function } \\
\text { normal } \\
\text { normal mobility } \\
\text { some decreased function } \\
\text { increased functional loss, loss of joint flexibility } \\
\text { marked functional loss; movements markedly } \\
\text { impaired }\end{array}$ \\
\hline $\begin{array}{l}\text { Adopted LENT-SOMA score for } \\
\text { endolaryngeal edema }[24,25]\end{array}$ & $\begin{array}{l}\text { Subjective } \\
\text { normal breathing } \\
\text { occasionally difficulty } \\
\text { intermittent difficulty } \\
\text { labored breathing }\end{array}$ & $\begin{array}{l}\text { Objective } \\
\text { no edema } \\
\text { edema of arytenoids only } \\
\text { additional edema of } \\
\text { aryepiglottic folds } \\
\text { diffuse edema of supraglottis, } \\
\text { but airway adequate } \\
\text { diffuse edema with significant } \\
\text { narrowing of airway }<1 / 2 \text { normal }\end{array}$ & $\begin{array}{l}\text { Management (respiration) } \\
\text { none } \\
\text { none } \\
\text { humidifier, steroids } \\
\text { temporary tracheostomy } \\
\text { permanent tracheostomy }\end{array}$ \\
\hline
\end{tabular}

limb edemas [20, 21, 28]. Characteristics of the three classification systems are described in table 2.

Patient's quality of life was assessed using a visual analogue scale (VAS). The VAS is a validated tool using a scale from 0 to 10 for estimation of the general health condition by the physician or the patient [29], whereby higher VAS values mean a lower quality of life of the patient. In this study we used a self-assessment of the quality of life by the patient.

Maximal treatment effect was recorded 4 weeks after the end of selenium treatment because the aim of this study was only to obtain data about the influence of selenium on developed edema and not about prevention of probably developing edema.

Pre- and post-treatment values were compared using the Wilcoxon test for two related samples. Values of $p<0.05$ were considered statistically significant.

\section{Results}

The pre- and post-treatment values of the different scoring systems are summarized in table 3 .

Using the scoring system of Földi [7] and Földi et al. [26], 10/16 patients (63\%) had an improvement of one stage or more, while with the five-item scoring system of Miller et al. [27] 12/16 patients (75\%) had an improve- ment of one grade or more. The pre- and post-treatment self-assessment of quality of life values were $7.9 \pm 2.3$ and $3.5 \pm 2.4$, respectively. The reduction of 4.4 points was statistically significant. Thirteen of the 20 patients $(65 \%)$ with interstitial endolaryngeal edema showed a substantial reduction of endolaryngeal swelling with normalization of endolaryngeal airways (fig. 1) proven by microlaryngoscopic findings. Therefore, tracheostomy was not necessary in these 13 patients. Five patients $(25 \%)$ received a temporary, and only 2 patients underwent a permanent tracheostomy.

Overall, selenium treatment was easy to deliver and well tolerated by all the patients. No potential seleniumrelated side effects were observed. Furthermore, no episode of erysipelas was observed in any of the patients.

\section{Discussion}

The present study shows that selenium supplementation resulted in a reduction of lymphedema as previously reported [8, 20-22, 30, 31]. For breast cancer patients, the present data demonstrate that selenium can enhance the 
Table 3. Pre- and post-treatment values of different scoring systems

\begin{tabular}{|c|c|c|c|c|c|c|}
\hline Scoring system & Evaluated patients & $\begin{array}{l}\text { Pretreatment } \\
\text { stage or grade }\end{array}$ & $\mathrm{n}$ & $\begin{array}{l}\text { Post-treatment } \\
\text { stage or grade }\end{array}$ & $\mathrm{n}$ & $\begin{array}{l}\mathrm{p} \text { value } \\
\left(\chi^{2} \text { test }\right)\end{array}$ \\
\hline \multirow[t]{3}{*}{$\begin{array}{l}\text { Modified Földi score for head and } \\
\text { neck edema }[7,26]\end{array}$} & HN (all) 16 & $\begin{array}{l}\text { stage } 1 \\
\text { stage } 2\end{array}$ & $\begin{array}{r}6 \\
10\end{array}$ & $\begin{array}{l}\text { stage } 0 \\
\text { stage } 1 \\
\text { stage } 2\end{array}$ & $\begin{array}{r}3 \\
10 \\
3\end{array}$ & n.s. \\
\hline & HN (unresectable) 10 & $\begin{array}{l}\text { stage } 1 \\
\text { stage } 2\end{array}$ & $\begin{array}{l}4 \\
6\end{array}$ & $\begin{array}{l}\text { stage } 0 \\
\text { stage } 1 \\
\text { stage } 2\end{array}$ & $\begin{array}{l}2 \\
6 \\
2\end{array}$ & n.s. \\
\hline & HN (resectable) 6 & $\begin{array}{l}\text { stage } 1 \\
\text { stage } 2\end{array}$ & $\begin{array}{l}2 \\
4\end{array}$ & $\begin{array}{l}\text { stage } 0 \\
\text { stage } 1 \\
\text { stage } 2\end{array}$ & $\begin{array}{l}1 \\
4 \\
1\end{array}$ & n.s. \\
\hline \multirow[t]{3}{*}{$\begin{array}{l}\text { Modified Miller score for head and } \\
\text { neck edema [27] }\end{array}$} & HN (all) 16 & $\begin{array}{l}\text { grade } 1 \\
\text { grade } 2 \\
\text { grade } 3\end{array}$ & $\begin{array}{l}4 \\
6 \\
6\end{array}$ & $\begin{array}{l}\text { grade } 0 \\
\text { grade } 1 \\
\text { grade } 2 \\
\text { grade } 3\end{array}$ & $\begin{array}{l}3 \\
8 \\
4 \\
1\end{array}$ & n.s. \\
\hline & HN (unresectable) 10 & $\begin{array}{l}\text { grade } 1 \\
\text { grade } 2 \\
\text { grade } 3\end{array}$ & $\begin{array}{l}3 \\
3 \\
4\end{array}$ & $\begin{array}{l}\text { grade } 0 \\
\text { grade } 1 \\
\text { grade } 2 \\
\text { grade } 3\end{array}$ & $\begin{array}{l}2 \\
4 \\
3 \\
1\end{array}$ & n.s. \\
\hline & HN (resectable) 6 & $\begin{array}{l}\text { grade } 1 \\
\text { grade } 2 \\
\text { grade } 3\end{array}$ & $\begin{array}{l}1 \\
3 \\
2\end{array}$ & $\begin{array}{l}\text { grade } 0 \\
\text { grade } 1 \\
\text { grade } 2 \\
\text { grade } 3\end{array}$ & $\begin{array}{l}1 \\
4 \\
1 \\
0\end{array}$ & n.s. \\
\hline $\begin{array}{l}\text { Adopted LENT-SOMA score for } \\
\text { endolaryngeal edema }[24,25]\end{array}$ & HN (all) 20 & $\begin{array}{l}\text { grade } 3 \\
\text { grade } 4\end{array}$ & $\begin{array}{r}12 \\
8\end{array}$ & $\begin{array}{l}\text { grade } 0 \\
\text { grade } 1 \\
\text { grade } 2 \\
\text { grade } 3 \\
\text { grade } 4\end{array}$ & $\begin{array}{l}5 \\
4 \\
4 \\
5 \\
2\end{array}$ & n.s. \\
\hline VAS [29] & HN (all) 36 & $7.9+2.3$ & & $3.5+2.4$ & & $\mathrm{p}<0.05$ \\
\hline
\end{tabular}

$\mathrm{HN}=$ Head and neck cancer; $\mathrm{n} . \mathrm{s} .=$ not significant; $\mathrm{n}=$ number of patients .

benefits of physical therapy in radiation-induced lymphedemas as previously reported $[8,9,20,21]$ by reducing the edema volume, improved skin fold index in limb edemas and the incidence of erysipelas in the group treated with sodium selenite compared to the control group [8, 22].

To date, little is known about the basic pharmacologic mechanism by which selenium reduces edema. In the affected limb of patients with chronic lymphedema, the production of free reactive oxygen and free radicals is enhanced as a result of lymphostasis, mechanical tissue compression, and chronic inflammation processes, triggered by an excess of interstitial proteins and cellular debris. This condition promotes a variety of degenerative processes, worsening lymphostasis and inflammation by tissue fibrosis [1, 22, 23]. A reduction of free radicals caused by selenium-induced activation of glutathione peroxidase (GPX) probably plays an important role in this pathologic process $[17,21]$. The selenium compound tested in this study belongs to the most efficient radical scavengers, with a very low toxicity profile [9], and, as selenocysteine, selenium is a component of selenoproteins, which have important enzymatic functions. These are selenium-dependent enzymes, where selenium functions as a redox center [32]. These enzymes are known to maintain membrane integrity, to protect prostacycline 

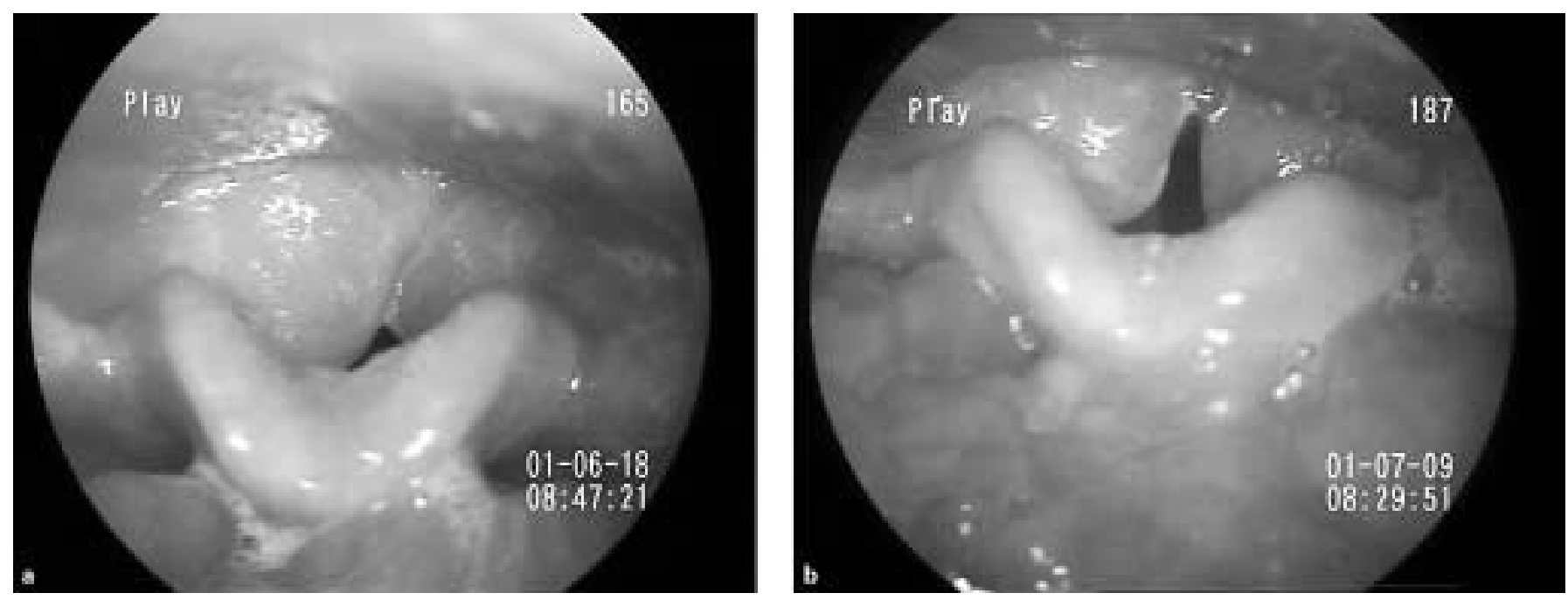

Fig. 1. Clinical aspects of endolaryngeal edema under selenium administration. a Endolaryngeal edema before administration of selenium showing hyperplastic tissue at the posterior commissure of the glottis and significant airway obstruction $<1 / 2$ normal. b Normal endolaryngeal aspect 4 weeks after selenium administration.

production, and to reduce the likelihood of further oxidative damage to biomolecules such as lipids, lipoproteins, and the DNA, which is associated with an increased risk of diseases such as atherosclerosis and cancer [33]. Administration of selenium leads to an increased activity of the endogenous antioxidative enzyme system of GPX, which is often decreased in patients with tumor disease [34]. Other preclinical studies [35] have shown that selenium is able to protect human endothelial cells from oxidative damage by inducing GPX and thioredoxin reductase. It must be kept in mind that the histologic structure of lymphatic vessels is completely different from that of blood vessels. In particular, beyond a single layer of endothelial cells, they have only a reticular fibrous network and not a media consisting of smooth muscle cells [36]. Horvarthova et al. [37] demonstrated in umbilical vein endothelial cells that the expression of glycoprotein adhesion molecules such as P-selectin is inhibited by selenium in a dose-dependent manner. Based on this data, Kasseroller and Schrauzer [8] hypothesized that in lymphedema patients, supplemental selenium should analogously suppress the expression of adhesion molecules and thus prevent activated lymphocytes from attaching to and clogging lymphatic microcapillaries. By the same mechanism, selenium unclogs lymph capillaries invaded by leukocytes and thus effects a spontaneous edema volume reduction.

Selenium in Lymphedema
Another positive effect on lymphedema could be the enhanced activity of the immune system after stimulation with selenium. So, Kiremidjian-Schumacher et al. [38] reported a significantly enhanced cellular immunologic reaction after administration of selenium, e.g. improved efficacy of cytotoxic $\mathrm{T}$ lymphocytes and other immunologic parameters in head and neck cancer patients. This may stimulate macrophage degradation of excess tissue proteins. Furthermore, immunostimulation may cause the lower incidence of erysipelas shown in our study and in the literature [8, 22].

A larger randomized trial with the addition of a control group and longer follow-up is needed to verify the findings of this study. The selenium treatment in the abovedescribed form seems to be cost-effective with median estimated cost of about $\$ 1,660\left(350 \mu \mathrm{g} / \mathrm{m}^{2}\right.$ sodium selenite p.o. daily over a median of 5 weeks, generally giving a total dose of $500 \mu \mathrm{g}$ per day). In contrast, lymphedema treatment by physical therapy can be expensive and timeconsuming. For arm edema, a compression sleeve and gauntlet cost \$65-100 each and last about 6 months. A compression pump costs about $\$ 4,000$. Manual lymph drainage costs about $\$ 75$ per session so that total costs for 6 months' treatment range between $\$ 3,900$ and $\$ 5,200$ depending on the number of sessions per week (minimum: 2). Complex decongestive therapy costs about $\$ 7,000$ for the recommended 4-week session. In this calculation are the costs for incapacity still excluded as well 
as possibly consecutive expenses for antibiotics in erysipelas episodes and surgical interventions [26]. For head and neck lymphedema, however, no comparable cost-benefit analysis has been performed, but we suppose that the selenium treatment is cost-effective in head and neck lymphedema as well.

\section{Conclusion}

The result of this study indicates a positive effect of sodium selenite on secondary head and neck lymphedema caused by radiotherapy alone or combined after surgery.

\section{References}

1 Petrek JA, Pressman PI, Smith RA: Lymphedema: Current issues in research and management. CA Cancer J Clin 2000;50:292-307.

2 Rockson SG: Lymphedema. Am J Med 2001; 110:288-295.

3 Weissleder H, Schuchardt C: Lymphedema of the arm following breast cancer therapy; in Weissleder H, Schuchardt C (eds): Lymphedema: Diagnosis and Therapy, ed 3. Cologne, Viavital, 2001, pp 187-213.

4 Weissleder H, Schuchardt C: Iatrogenic alteration of the lymphatic system; in Weissleder $\mathrm{H}$, Schuchardt C (eds): Lymphedema: Diagnosis and Therapy, ed 3. Cologne, Viavital, 2001, pp 156-174.

5 Paskett ED, Stark N: Lymphedema: Knowledge, Treatment, and Impact among Breast Cancer Survivors. Breast J 2000;6:373-378.

6 Megens A, Harris SR: Physical therapist management of lymphedema following treatment for breast cancer: A critical review of its effectiveness. Phys Ther 1998;78:1302-1311.

7 Földi E: The treatment of lymphedema. Cancer 1998;83:2833-2834.

8 Kasseroller RG, Schrauzer GN: Treatment of secondary lymphedema of the arm with physical decongestive therapy and sodium selenite: A review. Am J Ther 2000; 7:273-279.

9 Bruns F, Micke O, Bremer M: Current status of selenium and other treatments for secondary lymphedema. J Support Oncol 2003;1:121138.

10 Casley-Smith JR: Benzo-pyrones in the treatment of lymphoedema. Int Angiol 1999;18:3141.

11 Piller NB: Macrophage and tissue changes in the developmental phases of secondary lymphoedema and during conservative therapy with benzopyrone. Arch Histol Cytol 1990;53: 209-218.

12 Casley-Smith JR, Gaffney RM: Excess plasma proteins as a cause of chronic inflammation and lymphodema: Quantitative electron microscopy. J Pathol 1981;133:243-272.

13 Casley-Smith JR, Morgan RG, Piller NB: Treatment of lymphedema of the arms and legs with 5,6-benzo-[alpha]-pyrone. N Engl J Med 1993;329:1158-1163.
14 Loprinzi CL, Sloan J, Kugler J: Coumarininduced hepatotoxicity. JCO 1997;15:31673168.

15 Schuchardt C, Pritschow H, Weissleder H: Conservative treatment; in Weissleder $\mathrm{H}$, Schuchardt C (eds): Lymphedema: Diagnosis and Therapy, ed 3. Cologne, Viavital, 2001, pp 336-358.

16 Schünemann $\mathrm{H}$, Willich $\mathrm{N}$ : Lymphoedema of the arm after treatment of cancer of the breast: A study of 5868 cases. Dtsch Med Wochenschr 1997; 122:536-541.

17 Walley DR, Augustine E, Saslow D, Bailey S, Jeffs E, Lasinski B, Plotkin J, Walker M: American Cancer Society Lymphedema Workshop. Workgroup IV: Lymphedema treatment resources-professional education and availability of patient services. Cancer 1998;83:28862887.

18 Rockson SG, Miller LT, Senie R, Brennan MJ, Casley-Smith JR, Földi E, Földi M, Gamble GL, Kasseroller RG, Leduc A, Lerner R, Mortimer PS, Norman SA, Plotkin CL, RinehartAyres ME, Walder AL: American Cancer Society Lymphedema Workshop. Workgroup III: Diagnosis and management of lymphedema. Cancer 1998;83:2882-2885.

19 Ewald H: Radiotherapy of head and neck tumours and risk of lymphedema (in German). Z Lymphol 1996;20:21-26

20 Micke O, Bruns F, Schäfer U, Kisters K, Hesselmann S, Willich N: Selenium in the treatment of acute and chronic lymphedema. Trace Elem Electrolytes 2000;17:206-209.

21 Brenke R, Siems W: Adjuvant therapy in lymphedema. Z Lymphol 1996;20:31-35.

22 Kasseroller R: Sodium selenite as prophylaxis against erysipelas in secondary lymphedema. Anticancer Res 1998;18:2227-2230.

23 Beier A, Siems W, Brenke R, Grune T: Increased formation of free radicals in chronic lymphedema. Z Lymphol 1994;18:8-11.

24 Dietz A, Rudat V, Nollert J, Helbig M, Vanselow B, Weidauer $\mathrm{H}$ : Chronic laryngeal edema as a late reaction to radiochemotherapy. HNO 1998;46:731-738.

25 Rubin P, Constine LS, Fajardo LF, Phillips TL, Wasserman TH: RTOG Late Effects Working Group. Overview. Late Effects on Normal Tissues (LENT) scoring system. Int J Radiat Oncol Biol Phys 1995;31:1041-1042.
26 Földi E: Treatment of lymphedema and patient rehabilitation. Anticancer Res 1998;18:22112212.

27 Miller AJ, Bruna J, Beninson J: A universally applicable clinical classification of lymphedema. Angiology 1999;50:189-192.

28 Herpertz U: Measuring and documentation of edema. Z Lymphol 1994;18:24-30.

29 Johnson EW: Visual analog scale (VAS). Am J Phys Med Rehabil 2001;80:717.

30 Obenheimer H, Jankowiak P, Berlemann K, Hermann V, Diethelm A: Clinical and biological effects of selenium in edema; in Gonzalez $\mathrm{G}$ (ed): Lymphedema: New Perspectives in Research and Treatment. Zaragossa, 1976.

31 Peters GM, Herbert WD: Reduction of edema in brain tumors by selenium application. Acta Neurol Pathol Oncol 1957;11:351-353.

32 Whanger PD: Selenoprotein W: A review. Cell Mol Life Sci 2000;57:1846-1852.

33 Rayman MP: The importance of selenium to human health. Lancet 2000;356:233-241.

34 Mücke R, Micke O, Schönekaes KG: Serum selenium levels, glutathione peroxidase activities and serum redox potential levels in patients with untreated non-small cell lung cancer and adenocarcinoma of the rectum. Trace Elem Electrolytes 2003;20:148.

35 Miller S, Walker SW, Arthur JR, Nicol F, Pickard K, Lewin MH, Howie AF, Beckett GJ: Selenite protects human endothelial cells from oxidative damage and induces thioredoxin reductase. Clin Sci (Lond) 2001;100:543-550.

36 Bahadur S, Amatya RC, Kacker SK: The enigma of post-radiation oedema and residual or recurrent carcinoma of the larynx and pyriform fossa. J Laryngol Otol 1985;99:763-765.

37 Horvathova M, Jahnova E, Gazdik F: Effect of selenium supplementation in asthmatic subjects on the expression of endothelial cell adhesion molecules in culture. Biol Trace Elem Res 1999;69:15-26.

38 Kiremidjian-Schumacher L, Roy M, Glickman R, Schneider K, Rothstein S, Cooper J, Hochster H, Kim M, Newman R: Selenium and immunocompetence in patients with head and neck cancer. Biol Trace Elem Res 2000;73:97111. 